\title{
GROSS BRUKKAROS: A KIMBERLITE-CARBONATITE
} VOLCANO

John Ferguson*, H. Martin ${ }^{+}$, L.O. Nicolaysen* and R.V. Danchin ${ }^{f}$

* University of the Witwatersrand

+ Georg-August-Universität, Göttingen

$f$ Anglo-American Research Laboratories

The Gross Brukkaros massif lies at the southern extremity of the Gibeon kimberlite province in South West Africa; it is a well-formed shallow volcanic vent with a central depression whose diameter exceeds two kilometres and rises approximately 700 metres above the great Namaqualand plain. The country rocks surrounding the main crater at Gross Brukkaros form a well-defined up-domed collar whose structure has been described in some detail by Janse (1969). The vent is lined by a 130 metre succession of stratified non-pyroclastic microbreccias, blown out by repeated explosions of the central volcano. This activity cuts through the late Precambrian strata of the Nama Supergroup which underlies the microbreccias, and is dominated by vents and radial fissures having kimberlitic and carbonatitic affinity. A sheetlike monticellite peridotite intrusive is also present on the southern slopes of Gross Brukkaros.

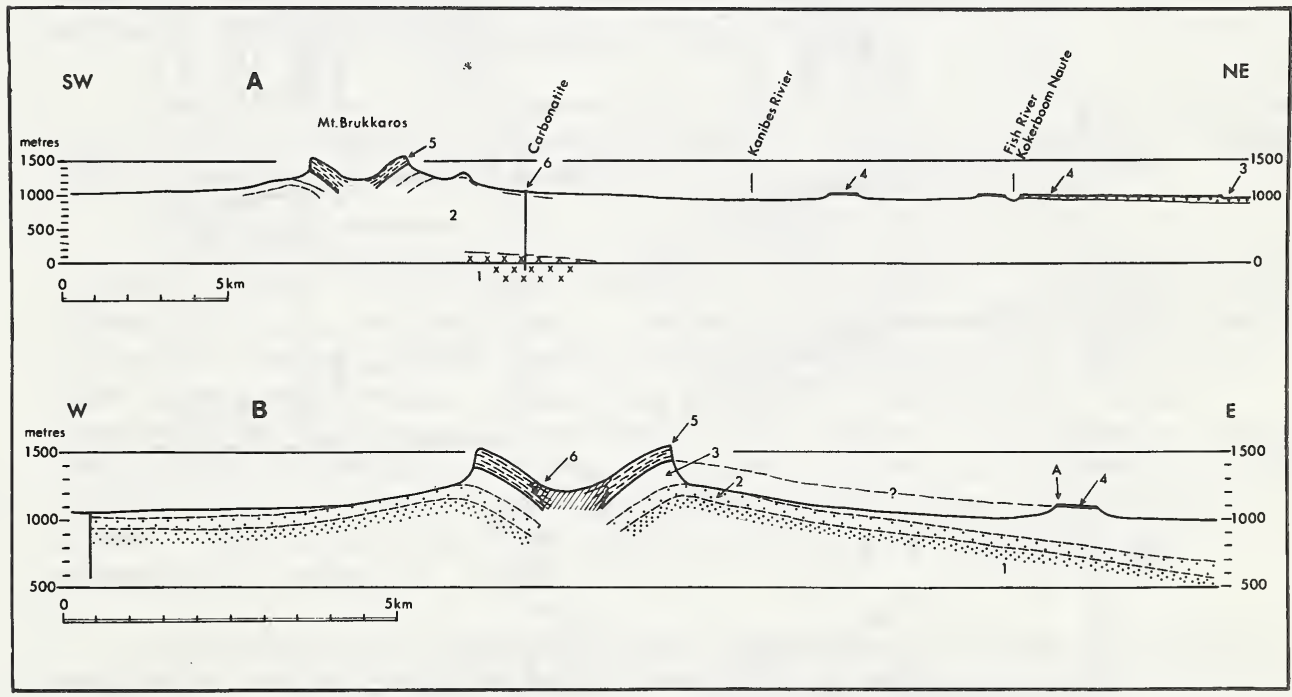

Figure 1 A. Section from Gross Brukkaros to Kokeboom Naute. $1=$ Pre-Nama basement, 2 = Nama Supergroup, 3 = Dwyka Group, 4 = Eolian quartzitic sandstone overstepping Dwyka and Nama beds with an angular unconformity, 5 = layered microbreccias, 6 = carbonatite vent with Basement inclusions.

B. East-West section. 1 to 3 = Quartzites, flagstones and shales of the Nama Supergroup, 4 = Eolian quartzitic sand- 
stone, 5 = layered microbreccia, 6 = contact of microbreccia of volcanic neck and layered microbreccia.

There is striking petrographic evidence of fenitisation, affecting both basement fragments and sedimentary fragments in the microbreccias. Pre-explosion fenitisation is demonstrated by metasomatism of some angular inclusions along one margin only, and by the restriction of some calcite veins to single inclusions. Post-depositional fenitisation is displayed by thick, steeply-inclined alteration zones spectacularly exposed in the high walls of a gorge cutting through the microbreccias. The layered microbreccias were originally of a pale-brown variety displaying angular fragments with the basement inclusions showing intact quartz grains. Post-depositional passage of carbonate and $\mathrm{K}-$ rich hematite solutions have been responsible for production of buff and red varieties of microbreccia respectively.

Pre-explosion fenitising solutions have produced a strong desilication of argillite fragments, and have introduced $\mathrm{Na}, \mathrm{Ca}, \mathrm{Mg}$, $\mathrm{Ti}$, $\mathrm{Fe}^{{ }^{+}}$, total $\mathrm{Fe}$ and $\mathrm{C}$ (Fig. 2). Post-depositional late-stage fenitising solutions have also produced a local enrichment in $K, P$ and $C$. Enrichment in the characteristic elements of the ultramafic suites is shown by data for $\mathrm{Cr}, \mathrm{Ni}, \mathrm{V}$ and $\mathrm{Sc}$. The elements particularly characteristic of residual associations, $\mathrm{Li}, \mathrm{Nb}, \mathrm{Be}, \mathrm{Zr}, \mathrm{Y}$ and $\mathrm{Sr}$, have also been introduced.
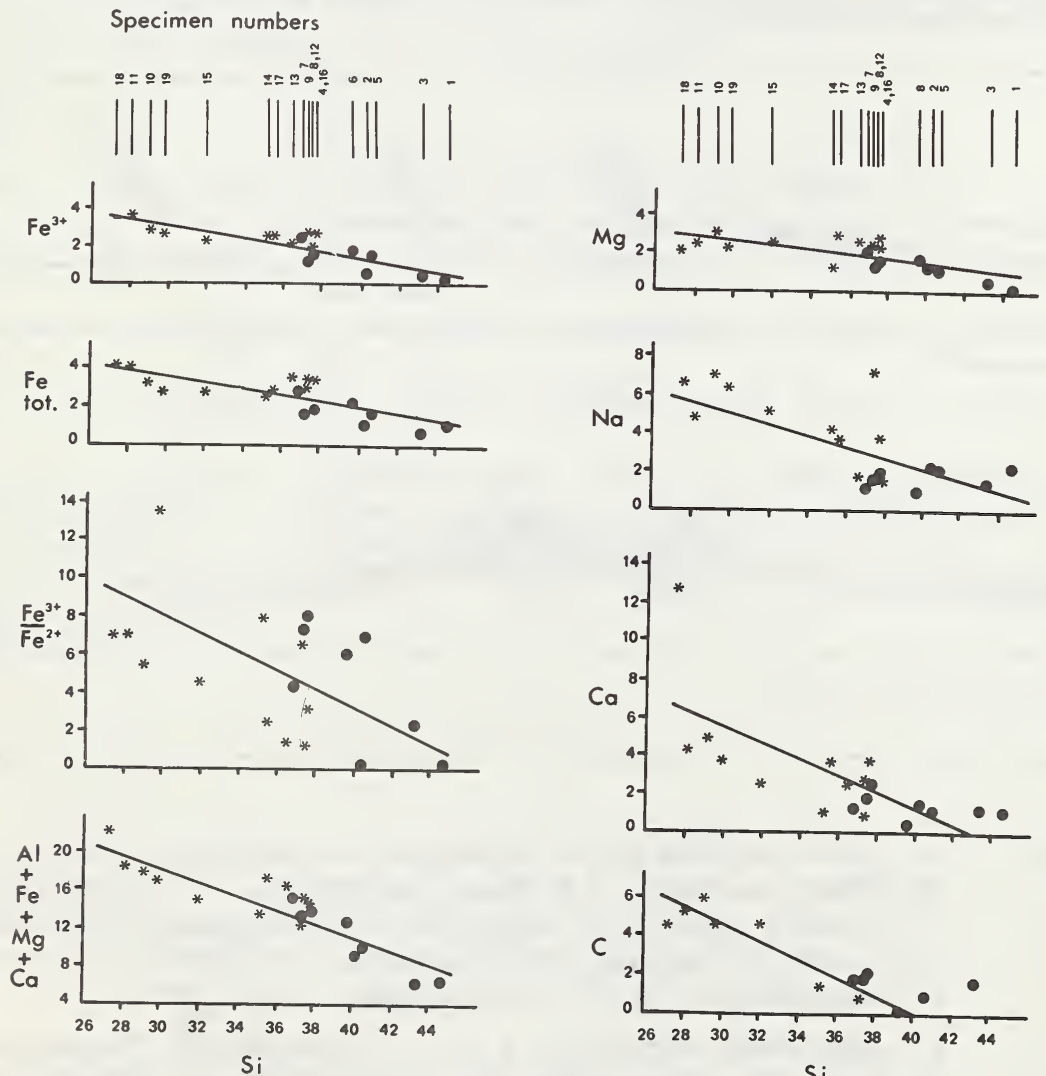

$\mathrm{Si}$ 
Figure 2. Variation of cation content of standard cell with Si for argillites and their fenitised equivalents. Solid circle = Nama argillites, star $=$ microbreccias.

Rocks exposed on the northern slopes of the Gross Brukkaros structure, in the subsidiary vents termed JI and LI by Janse (1969), have a matrix of carbonated kimberlitic rocks with 70 per cent of olivine pseudomorphs; phlogopite and perovskite also occur here. In vent JI, rounded fenitised granitoid inclusions are concentrically mantled by this kimberlitic rock. Similar autoliths have been recorded from a number of kimberlite pipes and are a feature restricted to diatreme facies (Ferguson et al, in press, ref. a, and Danchin et al., this volume). Autoliths are interpreted as nucleation of kimberlitic magma around solid fragments (Ferguson et al. op cit.). Between Gross Brukkaros and the kimberlite diatremes at Mukarob, some $70 \mathrm{~km}$ to the northeast, there are abundant calcitised dikes of kimberlite and olivine melilitite (Frankel, 1956). Janse (1971) noted the significant presence of a monticellite peridotite on the southern slopes of Gross Brukkaros. Two new chemical analyses of this rock reveal a composition almost identical to a specific group of kimberlites and, furthermore, to a group of melilite- and monticellite-bearing rocks (Ferguson et al. in press, ref. b). $\mathrm{Rb}-\mathrm{Sr}$ isotopic data for mica and carbonate fractions taken from the monticellite peridotit body $_{6}$ at Gross Brukkaros yield an age of $84 \mathrm{~m} . \mathrm{y}$. and an initial $\mathrm{Sr} / \mathrm{sr}$ ratio of 0.7041 (D. Barrett personal commun ication). This Sr-isotope ratio is markedly similar to those obtained for fresh kimberlites (Berg and Allsopp, 1972 and Danchin et al., this volume)

Heavy mineral concentrates from soil samples within the crater and its immediate surroundings contain pyrope and chrome diopside. Kimberlitic ilmenite has been identified in the microbreccias.

In the CMAS tetahedron of O'Hara (1968) kimberlites lie on a welldefined olivine control line trending sub-parallel to the CAM plane (Danchin et al., this volume). The melilite- and monticellite-bearing ultramafic rocks plot at the extremity of the kimberlite trend with some degree of overlap, indicating possible consanguinity (also supported by the isotope chemistry). The control line of these ultramafic rocks associated in space and time produces an inflection in the olivine control line of the kimberlites trending away from the MAS plane. This inflection represents an equilibrium condition at a pressure in excess of $30 \mathrm{~Kb}$.

No evidence was found of shock metamorphism at Gross Brukkaros. A meteorite impact origin for the structure is rejected on several grounds. The suggested alternative model is that kimberlitic magma was generated at a depth in excess of $100 \mathrm{~km}$ and rapidly ascended the mantle and lower crust reaching a depth of $2-3 \mathrm{~km}$ below surface. At this level a carbonatitic fraction unmixed and also reacted with the olivine and ilmenite, to form monticellite and perovskite respectively, with the dense mineral phases and xenoliths settling out of the residual silicate magma. It is also possible that the rise of the kimberlite magma was arrested at a depth in excess of $100 \mathrm{~km}$ where equilibrium conditions included the reaction of olivine and ilmenite to produce melilite and perovskite respectively. This latter magma 
would then rapidly rise to the hypothetical depth of $2-3 \mathrm{~km}$ below surface where the melilite would react to produce monticellite. At this high level in the crust an immiscible carbonatitic top developed. The carbonatitic and alkaline ultramafic magmas were in equilibrium, together with their alkali volatile phase which impregnated and fenitised the wall rocks in joint zones. The volatile pressure built up until it was just greater than the lithostatic pressure, and bulging of the roof began. With a breach of the containment of the volatile phase, there was violent disruption of the roof. Much of the brecciation and fine disruptive veining is interpreted as episodic failure in containment of fluid pressure. At lower pressure, melilite reacted to produce monticellite and this degassed magma intruded the outer flank of the volcano in the initial stages of eruption.

Berg, G.W. and Allsopp, H.L. 1972. Earth and Planetary Sci. Letters $16,27-30$.

Danchin, R.V., Ferguson John, McIver, J.R. and Nixon P.H. This volume.

Ferguson, John, Danchin, R.V. and Nixon, P.H. in press (a) In: Lesotho Kimberlites (P.H. Nixon,Ed.)

Ferguson, John, Nicolaysen, L.O., Martin, H. and Danchin R.V. in press (b) Nature, London.

Frankel, J.J. 1956 Trans. Roy. Soc. S. Afr., 35, 115-123.

Janse, A.J.A. 1969. Geol. Soc. Amer. Bull. 80, (4), 573-586'

1971 Trans. geol. Soc. S.Afr., LXXIV, 45-56.

O'Hara, M.J. 1968. Earth Sci. Rev., 4, 69-133. 